\title{
ONE PERSON'S WEIGHT: SYLVIA TOWNSEND WARNER AND HERBERT HOWELLS
}

\section{Richard Searle}

Four letters and a short postcard written by Sylvia Townsend Warner to the young composer Herbert Howells, over the course of eleven months between September 1917 and July 1918, survive in the Herbert Howells archives in the Royal College of Music, London, Each communication is in response to one written by Howells, of which none has survived. This small quantity of one-sided correspondence is of interest to Warner scholars and enthusiasts because it belongs to a period in Warner's life that is least known about in depth: her early adult years, when Warner had recently begun her musicological studies of Tudor church music with $\mathrm{Dr}$ (later Sir) Richard Terry. They show an alternative side to her personality and character: one that reveals youthful spontaneity, irreverence, disrespect and impertinence used for effect. These are absent from her later, edited, 
published letters. In the following paragraphs each piece of the correspondence is reproduced verbatim and no attempt has been made to correct Warner's spelling or punctuation errors.

Herbert Howells was born in 1892, one year before Warner and apart from their contemporaneousness their cultural and social backgrounds could not have been more disparate. They shared a love of music and literature, stimulated through their diverse types of education, which endured respectively throughout their entire lives. At the time they were corresponding with each other, both were composing music. Warner came to know Howells through her work editing Tudor Church Music (Buck, et al eds. 1922-29) when both were in their early twenties, and a kind of ephemeral friendship developed during that time. For Warner's early life the only comprehensive source is the indispensable biography by Claire Harman ( 1989). There are two major published sources for biographical information on Herbert Howells (Palmer, 1992; Spicer, 1998).

Howells was born in the small Gloucestershire town, Lydney, on the west side of the river Severn. He was the youngest of eight children born into the family of a builder. Herbert's father Oliver played the organ at the local Baptist church but, although the boy was to learn to play the church organ too, it was from his eldest sister that Herbert first began to learn music and to play the piano. His formal education began at the Lydney Church of England Elementary School from where he was awarded a scholarship to Lydney Grammar School in 1905. His headmaster noticed that music was Herbert's major strength and secured sponsorship for him to be given proper music lessons with Sir Herbert Brewer, organist at Gloucester Cathedral. This arrangement continued till 1909 when Howells, aged sixteen, became an articled pupil to Brewer joining two other articled pupils, the poet composer Ivor Gurney and Ivor Novello, the composer, actor and entertainer. In 1912, following the slightly older Gurney, Howells moved to London on an open scholarship to study at the Royal College of Music 
(RCM) under some of the foremost teachers of the age. Also in 1912, he had successfully entered the Associate examination of the Royal College of Organists (RCO); this being the first in a succession of qualifications and prizes awarded to him as a student. Indeed Howells' student career at the RCM was scintillating. Success came not only through his studies but with the compositions he wrote during those years, of which several were played before college audiences by college musicians. He also found success with the annual RCM essay competition and he contributed articles on music to The Athenaeum.

However, in 1915, Howells was diagnosed with Graves disease, an autoimmune complaint that causes the thyroid to become overactive, and he was given only nine months to live: the successful career that awaited him seemed on the verge of disintegration. He became a guinea-pig in being prescribed previously untried radium treatment, administered by injections in his neck: his survival into his ninety-first year is testimony to the efficacy of such novel treatment. Yet, the process and period of recovery were long. Howells continued working at his music albcit with the continual interruptions of travelling twice weekly from his Lydney home, to St Thomas's Hospital in London, to undergo his treatment.

In his final year at the RCM, 1916, he composed among other music a Piano Quartet in A minor which he submitted to the Carnegie United Kingdom Trust (CUKT) as his entry to the same competition for unpublished compositions entered by Wanner (Mutti, 2011). This is the first crossing of their paths although they seem not to have met until a few years later. Howells' Piano Quartet was one of the seven works chosen in 1917 as worthy of publication by the adjudicators and the first to be published under the scheme.

As his studies at the RCM were drawing to an end, Howells needed to find gainful employment and it came his way, in February 1917, with the offer of a position as assistant organist at Salisbury Cathedral. He took up the post but was forced to relinquish it after only a few months because of his illness; and with no means of 
regular financial support destitution beckoned. His saviour, one of the Carnegie competition adjudicators, Dr Hadow (later Sir Henry) appealed to the CUKT to make Howells' position a special case for a financial grant 'to tide him over... until he is sufficiently recovered to take up his career' (Hadow, 1917). To have agreed to that particular request would have established an uncomfortable precedent in the use of Carnegie funds but it was overcome by the CUKT's proposing that Howells should become a paid assistant to Terry, then engaged in editing manuscripts for Tudor Church Music (Searle, 2011). Howells was already known to Terry 'who had performed his student setting of the mass at Westminster Cathedral as carly as 1912 and had encouraged the composer... to write a cappella motets... for performance alongside newly rediscovered examples from the $16^{\text {th }}$ Century' (Andrews, 1995). At the Music Sub-Committec meeting of the CUKT dated 3 August, 1917, not only was Howells' appointment as Terry's assistant confirmed but also Warner's similar position on the identical salary of $£ 150$ per annum (Carnegie, GD 281/38/46).

Hadow's letter had stated 'the doctor prescribes a period of complete rest as the only hope of recovery' and Terry initially asked Howells to work on the rather mundane activity of creating short scores ${ }^{\prime}$ from completed works, because the CUKT trustees were concerned that he shouldn't be overworked. Howells wrote to Terry about the task and in response to a point in question Howells raised, Terry introduced 'Miss Warner' by name in his letter of reply:

you say about the help which the parts are to you in deciphering the music, so in the next batch I send you I will ask Miss Warner, who has the originals, to send them to you with the scores.

Terry, 1917

Howells also wrote at this time to Percy Buck, who may already have been known to him perhaps through their respective associations with the RCM, no doubt 
explaining his position and asking if Buck would take him on a visit to a Cathedral library in search of original Tudor music manuscripts. Instead of answering the request himself Buck seems to have passed it to Warner for reply. She is at once friendly and optimistic, although somewhat girlishly flippant when referring to the composer Robert Fayrfax at St Albans as Flayrfax. Her concluding, positive statement of solidarity in the task ahead is calculated to encourage Howells. Warner's reply reads:

24.9.1917

Dear Mr Howells,

P.C.B[uck] has told me that you wrote and asked him about doing a mutual Cathedral. He is always fearfully busy in term time, so I'm afraid any such little excursions will have to be shut down till the Christmas holidays. Meanwhile, would you like to go over to St. Albans one day with me?

I don't think we're likely to find much there: but anyhow its rather a jolly place, and as old $O$ quam glorifica [author's italics] Flayrfax [sic] hung out there once, theres always a chance of something turning $\mathrm{up}^{2}$. Anyhow, let me know when you're next in town and we could lunch together and have a talk.

I expect you feel as I do - that there's enough in this job to keep onc learning all one's life: it's not a bad feeling.

Howells Archive 7832/386a

In another letter written by Terry to Howells on 16 January 1918, Warner's name crops up again, in the context of Howells' learning the early musical notation:

I shall enjoy putting you through your paces in the matter of the old notation, and when you have 'put the wind up' the ligatures ${ }^{3}$, 
you can talk to that knowledgeable person Miss Warner, who will no doubt knock sparks off you on the point, as she does with us all

Terry, 1918

Terry appears to assume that Howells does not yet know Warner, which may well have been true.

In the next letter Howells wrote to Warner it must be assumed that he had expressed his frustration at not bccoming involved with transposition from the original manuscripts and he was feeling rather wasted and derelict. Warner replied while Howells was convalescing at a brother's house in Yorkshire. She explains to him how she is not responsible for his not receiving the music that Terry had promised. She talks about her studying the manuscripts of Nicholas Ludford ${ }^{4}$ in the British Muscum. a composer whose works were not included in the ten volumes of Tudor Church Music. She offers to send Howells some motets by Robert Whyte. More intriguing, however, is her confession that she had been cocreed by Buck and Terry into writing a paper, rather than undertaking it willingly, and she claims to have found it a bore to prepare.

$$
\text { 25: 2: } 1918
$$

Dear Mr Howells,

He never breathed a word to me about sending you scores. I'm so sorry. I hope you haven't cursed me for incivility, but I expect you have.

I always take all finished scores to Westminster, but I will get hold of some and despatch them as soon as I can. For the last two months or so I have been working at the Brit. Mus. at a man called Ludforde. [an odd man: ordinarily rather mellifluous in his part-writing, and then all of a sudden assaulting one with the most arbitrary noises. But quite entertaining on the whole.] However I won't send you him just yet, as I 
can't send the MSS. for comparison! I think I'd better send you some motets of Robert Whyte's, as I have rotographs of all the parts, and fairly legible ones. He is a really great man.

I'm afraid you're having a dreary time of it. Compulsory dereliction is a bad state of things. Alas! That I cannot come to York and do the Minster with you. I should love to: but at the moment I am fast bound in my particular gate. We are moving in March: my mother to Devonshire, I to London: and I spend my time among house-agents, plumbers, electricians, solicitors and people of that ilk. No fun at all.

When 1 am settled in town I hope you will come and sec me. I want to have a long talk with you about Tudors and Elizabethans. For one thing, l'm sure you ought to be doing something gayer than short scores. Wouldn't you prefer to score directly sometimes? We've got a photostat of our own now, and you could have facsimiles to work from. Let me know sometime how you feel about this. Also we must do a mutual Cathedral Library some time.

If you are up to it, and feel inclined to, you might cast your eye over the York Library. Keep a good look-out for single part-books, especially tenor and counter-tenor ones. I've set my heart on finding the missing tenors of some Byrd Motets Buck has been scoring at $\mathrm{Ch}$. Ch. ${ }^{5} \mathrm{I}$ believe I've got on the trail of one or two. I think it will end in a clear call to make thematic indexes, - or indices or whatever the right people call them - of all the scattered part books in the Kingdom. No other kind of index will serve, because half the time the parts have neither attribution or title. 
There's a Committee meeting looming ahead. We hope Hadow is coming to it. And I hope you are coming too. Your presence mitigates considerably my position of Susanna in a den of Elders. It will be worse than ever this time, because feebly yielding to the steamroller persuasions of Buck and Terry, I've done a dreadful paper for them on the Punctum Perfectionis ${ }^{6}$. [author's italies] It has been the most intolerable bore to do. And will no doubt be as tedious to others as it is to me. Its bad enough to have to extemporise those blinking minutes, but I am powerless before my better impulses, and always getting let in for meritorious acts like this.

I went and heard The London Symphony? last Monday. Adrian Boult, that rather mushroom-faced friend of Allen's conducting. It did not go very well. In fact it dragged: and the harp passage in the last movement was far too loud and obvious. It made what should have been elusive merely rather banal. It is having another performance in three week's time or so. I hope it will be a slicker and less conscientious rendering.

This is an awful affliction of a letter. But you must take it as kindly meant, and a would-be diversion in your exile. Scores and scripts will follow.

Howells Archive 7832/386b.

There had been a further delay in delivering the rotograph copies of original music manuscripts, presumably music by Robert Whyte, to Howells and Warner wrote a postcard to explain the hold-up:

I'm afraid there has been some delay about sending off your scores. Many of them are 
down for performance this Easter, and in the hands of the copyists. But I heard from R.R.T[erry] today and he has scratched some together.

S.T.W.

Howells Archive 7832/386c

In Warner's following letter she is once more immediately apologetic regarding the non-delivery of the promised music. Although she continues formally to address him as $\mathrm{Mr}$. Howells, this is a more genial letter even than her previous ones. She touches sympathetically on Howells' ill health and again employs immature impertinence and discourteousness in the attempt, one imagines, to raise his spirits. She actively wants to become his future guide and advisor on scoring Tudor church music, but, while telling him so, she would have been aware that his full recovery was at that time far from certain. She talks of the frustrations of obtaining her own flat:

Dear Mr Howells,

It is the very devil about the scores. Every time I sec Terry I harry him about them, and I'm afraid they haven't got off yet. Its this way. He's just moved house and gone to Belzise - Belsize I mean - Park: and taken all the scores with him. And having an Irish cook he always starts late for the Cathedral: and always forgets the scores. It is going to be a pestilential nuisance before long not having an atelier somewhere to keep all our papers and books of reference. I mean to fight a good fight about it at the next meeting, and the next and the next. There's nothing so persuasive as continued unpleasantness, more especially if its backed by the highest motives. 
But you are certainly going to score. I could teach you in two days. So the moment you feel up to it, come along and tell me. And I'd love to do Salisbury, I've never been there: and I foresee that before long I shall be a gibbering idiot from over work, and badly in need of an Episcopal week-end as a rest cure. I am having the most devastating time finding a flat. 1 got hold of a good one, and made all the arrangements, and was purring to myself over such an intelligent act - lo! The dam thing has been reft from me, because of the entire inability of the decorator to put it into habitable order. So now I am a waif again. As far as I can see I shall be reduced to sleeping in the Park and washing in the Serpentine.

Enough of my woes. 1 do hope Yorkshire is doing you good. Health is more ill to be in scarch of even than flats, and I do feel for you, although I've never said anything, because I thought you'd be sick of talking about it, most likely. As for calling yourself 'so much useless lumber' that's hallucination - or bosh, in the common tongue. You can't help it just at present: and later on I hope you will be able to do some scoring, and help me perhaps in tracing some of the stray parts.

Love from P. C. B. the requisitioned the village idiot, organist I mean.

Howells Archive 7832/386d

In Warner's final letter of this group she responds to Howells' wish to become less formal in their correspondence with an amusing excursion into her family history. She also remembers travelling through the Cotswolds, on her way to St. Michael's College, Tenbury and describes with literary allusions the landscape she passed through. Once more she lights on his well-being 
and concurs at a suggested trip together, to Oxford. Warner certainly went to Oxford in pursuit of Tudor music manuscripts (Searle, 2011) but whether she was accompanied by Howells on any occasion is not known. She wrote,

Dear Mr Howells,

Sylvia? yes of course, but I cannot possibly call you Herbert. I had a cousin called Herbert, who was a clergyman ${ }^{9}$ and would come in to Sunday supper like the pale martyr in his hairy shirt [that quotation seems to have got rather dishevelled] and after refusing all food on the grounds of fatigue, would eat both wings and the breast of a chicken, like Tartuffe" ${ }^{3 \prime}$. Does that convince you?

'Somewhere in the Cotswolds' sounds pleasant. I dawdled through that part of the world last summer on my way to Tenbury", and looking out of the window saw mousecoloured and mole-coloured and dove coloured farmsteads, and the very same orchards where Master Shallow grew his pippins, which as you will remember (nny Father made frequent use of that turn in teaching: he said it was the polite sophism for 'no doubt you have forgotten.') he ate with a dish of carroways ${ }^{12}$. Having been in Scotland I have eaten carroways with most things, including cold beef, but l've never tried 'em with apples. Do you think they would be a good mix?

But I'm sorry theres no sleep o'nights. Of all the hundred and one infallible expedients (including biscuits and subsequent crumbs) that I have had urged upon me against insomnia, the only thing I have found to be the least use is to give one's mind to 
breathing deeply and carefully. 'Polar Bears', dance they never so lumbringly, are not the slightest use $\mathrm{e}^{13}$.

Yes, we must go to Oxford. I'm really looking forward with pleasure to doing so. But let's try to hit a time when Allen is there. He is so kindly, and I want to rag him about his Professorship ${ }^{14}$. I am going into Kent next week to play Lucina - Egeria ${ }^{15}$ to a young man of my acquaintance who has recently been brought to bed of a novel, ("Growing Pains." good title, I think.) ${ }^{16}$ and then to Devon for a rest: but after that I'm at your service.

Although he continued to undergo radium treatment, Howells recovered from his life-threatening condition sufficiently to return to London and to take part, at least once, we can say with cerlainty, in the regular meetings of the TCM editorial pancl. In his first diary new/y begun at the opening of 1919 , he records,

Thursday $13^{\text {th }}$ February, 1919 (London)
At 10.30 am there assembled at Westminster
Cathedral in Solemn Conclave, Dr. Terry,
Miss S Townsend Warner, Rev. Dr EH
Fellowes, Prof. Percy Buck, Rev
Ramsbotham and my little self... in
committee on the Tudor Mss. T'was a very
protracted business. I should think Taverner
turned in his grave to rub his burning Tudor
ears! Somewhere in Victoria St. we
afterwards lunched together - save Terry,
who possibly went off to his Den to sleep off
the effects of the committee discussions...
Howells Archive reference 8900. a.

On the evening of that TCM committee meeting Howells and Warner attended a concert together, organised by the British Music Society, at which his 'Carnegic Piano 
Quartet' was played. They encountered Adrian Boult (later Sir Adrian) there who berated Howells for bringing a guest to the performance when only members of the Society were invited to attend. Subsequently, Boult wrote to Howells to apologise for being 'blatantly rude to your friend (Miss Townsend Warner, I think) and not over polite to yourself' (Boult, 1919). Were it not for Boult's letter we should not have known of Warner's attending the concert with Howells because, although he makes mention of the concert in his diary, he is silent on her presence; nor does he say anything of the rebuke that prompted the apology.

Two days later Howells spent some time with Warner at her Bayswater home when he enjoyed her conversation sufficiently to record,

Saturday $15^{\text {th }}$ February. 1919 (London)
Little - if any - work gets done when I'm in
London, tho I suffer from an extreme of
business and mobility. So does STW's mind
- and so too, (as a consequence) her
conversation. I had two hours fun out of it at
125 Queens Road, Bayswater this morning.
Howells Archive reference 8900 .a.

Howells diaries frequently serve as simple appointments indicators. Furthermore, there are significant numbers of blank dates making it impossible to know where he was or what he was doing on those days, or whether he was present at more than the one meeting of the TCM editorial committee. Similarly, we cannot know if he and Warner continued to meet or go to concerts together. His patchy diaries record scheduled meetings with Terry and Buck in 1919, without revealing their true nature or purpose, and on further occasions subsequently over several years, but none with Warner. In fact there is no further mention of her anywhere in the Howells archive.

By the beginning of 1920 , the CUKT recognized that Howells had recovered sufficiently to find full-time employment. Their minutes of February 25, 1920 record 
the suggestion that he should be as a temporary measure 'employed as a teacher at the Royal College of Music'. A generous grant of three hundred pounds was set aside for him by the Trust, to be paid "either in a lump sum or in two annual gifts of $£ 150$, this sum to be regarded as the final assistance which the Trustees would give to $\mathrm{Mr}$. Howells' (Carnegie, GD 281/41/228). Thus the composer officially moved on from the TCM project to accept an appointment at the RCM where he remained as a composition teacher for sixty years, till his retirement in 1980. Since Howells appears to have retained most of the letters he received over the decades, that there are none more from Warner, and she receives no further mention in his diary, suggests strongly that their association came to an abrupt end sometime in 1919.

In her celebrated biography of T. H. White Warner draws the analogy between protracted correspondence and a bridge "that carries the weight of one person at a time. When the correspondents meet the bridge collapses" (1967 p. 219). Five communications is far from being protracted correspondence but their meeting, both alone and in committee, may have caused that particular bridge to collapse nonetheless and rather bears out Warner's assertion. It may also provide early evidence in support of Claire Harman's theory (Harman, 1989 p.309) that Warner had 'depended on distance and separateness' among the friendships she valued most highly: all the while Howells was remote from her and remained unknown to her their communication flourished.

The few letters to Howells, possibly the only ones extant from her early twenties, are sufficient to inform us about certain aspects of Warner's emerging personality and character. She exhibits warmth, sincerity and generosity towards the composer from the outset, when she could be forgiven had she taken umbrage over his recent, spectacular, success at the Carnegie competition when her own submission gained not a mention from the adjudicators. Warner was not one to entertain rancour; a personal quality developed no doubt from childhood. Lynn Mutti has suggested that Warner was more 
comfortable writing words than music, so perhaps her competition failure was simply shrugged off or may even have confirmed a latent suspicion that being a composer wasn't going to be her destiny (see Mutti, 2011). In either case, Howells' brilliant success didn't affect her.

Despite her use of the formal 'Dear Mr. Howells' throughout, Warner is at once at ease in her correspondence: the formality may indicate that they hadn't met till after their brief exchange of letters had ceased. She gives welcoming encouragement to Howells about the TCM project while confidently offering to teach and mentor him. She displays an openness about her personal circumstances with regard to hunting for a flat; offering him a personal anecdote about her family; and freely giving her opinions, her likes and dislikes, where relevant to her responses to his letters. Warner's sense of humour surfaces naturally but her use of disrespect and ungraciousness towards mutual acquaintances is interesting and offers us a different side to her personality. Both parties were in emotional relationships with others at this time; Howells with his future wife and Warner and Percy Buck had become lovers in 1913 (Harman, 1989 p.24) making it unlikely that she was appealing to him in any skittish or flirtatious way. Her personal remarks were meant for Howells' eyes only and were written with such youthful spontancity as to suggest harmless mockery employed merely as a device for lifting Howells' spirit in his dejection.

When Warner uses literary references and allusion to illustrate a point she quotes quite naturally and without conceit to impress; Warner expected Howells to recognize her sources. Howells could certainly have known the reference to Susanna and the Elders from the Old Testament, and from Henry IV Part 2, and possibly the reference to Tartuffe, but it is less likely he would have known the Hodgson poem or the Baudelaire, were either of them Warner's source for the lumbering polar bears. Such citations can be interpreted as simply illustrative of the breadth of her reading. 
Warner records in her published diary entry for 23 October, 1929 (1994, p.46) meeting Howells once more, unexpectedly, ten years after their correspondence concluded, when attending a Delius concert with her friend Victor Butler. Wamer says Howells asked her if she were still composing music or pursuing her writing. However, Howells makes no mention anywhere in his sporadic diary for October that year either of the concert or of meeting Warner. 23 October fiustratingly has no entry, but he cryptically schedules a Delius concert nine days later, on 1 November, 1929, at the Queen's Hall (Howells Archive reference 8900.j). Whenever it took place, that personal encounter was in all likelihood their last. Their bridge had well and truly collapsed.

\section{NOTES}

1. A short score is a version of a full orchestral or vocal score reduced into fewer staves; as, for example, in a piano version of a composition.

2. Robert Fayrfax (1464 - c. 1521) Court composer to Kings Henry VIl and Henry VIIl. The mass $O$ quam glorifica ( $\mathrm{O}$ how glorious art thou) was written by Fayrfax as an academic exercise for his Doctorate of Music at Cambridge in 1504.

3. Originating with plainsong notation, ligatures may be defined as the marks that bind together two or more notes sung to a single word syllable. From the $16^{\text {th }}$ century the use of ligatures began to die out as sequences of notes sung to the single syllable became linked by a slur sign, as is common today.

4. Nicholas Ludford (c. 1485 - c. 1557) Singer and composer at St Stephen's, Westminster.

5. Christ Church Cathedral, Oxford.

6. The Point of Perfection in XVI Century Notation, by Sylvia Townsend Warner. The Proceedings of the Musical Association, vol. XLV, February, 1919, pp 67 74. Warner's paper was well thought of by the person 
who reviewed it for the Musical Times, despite her unease about it.

7. Symphony No. 2, A London Symphony, by Ralph Vaughan Williams, $1912-13$.

8. Hugh Percy Allen (later Sir Hugh) (1869-1946) Musician, academic and administrator. He was a leading influence on British musical life in the first half of the 20 th century. Organist of New College, Oxford and conductor of the Oxford Bach Society, he took over the established London Bach Choir in 1908, with a membership that included Ralph Vaughan Williams and Adrian Boult. Warner sang continuously with the London Bach Choir from 1916 to 1923 and would have known Allen from that activity.

9. Cousin Herbert was probably George Herbert Statham, born in 1842. He was rector of St Mark's in Torquay, from 1884 to 1922. He married Emily Florence Dicken a distant relative of Warner's on the female line of the Hudleston side of her family.

10. Tartuffe ou l'Imposteur. Play by Molière (1622 1673) written and first performed in 1664. Warner's reference is to Act 1, Scene 5 .

11. Tenbury Wells in Worcestershire. Warner visited St Michael's College, probably with Buck in September 1917, where she discovered the important collection of Tudor church music known today as the Tenbury Manuscript, now in the Bodlcian Library, Oxford.

12. Shakespeare, King Henty IV Pant 2: Act V Scene III.

13. Polar Bcars are known to dance in a clumsy fashion but, Warner's descriptive language seems to imply quotation; could she be loosely citing Ralph Hodgson's poem, published in 1917, The Bells of Heaven? Another, perhaps more likely, possibility is The Wild woman and the fashionable coquette, by Charles Baudelaire (1821 1867) from his collection of prose poetry, Le Spleen de Paris (Paris Spleen! published in 1869.

14. Hugh Allen was elected to the Heather Professorship of Music at Oxford in the summer, 1918. 15. In Roman mythology, the nymph Lucina, in the form of Goddess of Light was by derivation the goddess of 
childbirth, because the newly bom child is brought out into the light. The nymph Egeria was deemed to bring out the baby without difficulty from its mother's belly.

16. Probably Stephen Tomlin who had family roots in Kent Tomlin is buried at the church of St Nicholas, Ash, near Canterbury, Kent.

\section{WORKS CITED}

ANDREWS, P. (1995) 'A Matter of National Importance, Herbert Howells and the Carnegie United Kingdom Trust'. Organist's Review, LXXXI, 1995, pp32-35. BOULT, A. (1919) Letter to Howells dated 15 February. Royal College of Music, Howells Archive: 7832/42a BUCK, P. et al. eds. (1922-1929) Tudor Church Music. Oxford: Oxford University Press. 10 vols.

CARNEGIE UNITED KINGDOM TRUST, Tudor Church Music archives files GD 281/38/46 and GD 281/41/228. National Archives of Scotland, Edinburgh. HADOW, H. (1917) Letter to the Carnegie United Kingdom Trust, June 1917. Carnegie United Kingdom Trust: file GD 281/38/46, National Archives of Scotland, Edinburgh.

HARMAN, C. (1989) Sylvia Townsend Warner. A Biography. London: Chatto \& Windus.

HOWELLS, H. Herbert Howells Archive reference 8900 a. Royal College of Music, London.

Herbert Howells Archive reference 7832/386a Royal College of Music, London.

Herbert Howells Archive reference 7832/386b. Royal College of Music, London.

Herbert Howells Archive reference 7832/386c. Royal College of Music, London.

Herbert Howells Archive reference 7832/386d. Royal College of Music, London

Herbert Howells Archive reference 8900 j. Royal College of Music, London.

MUTTI, L. (2011) 'The Ambivalent Composer and the Carnegie Competition'. The Journal of the Sylvia Townsend Warner Society, 2011, pp. 21 - 36. 
PALMER, C. (1992) Herbert Howells. A Centenary Celebration. London, Thames.

SEARLE, R (2011) 'Sylvia Townsend Warner and Tudor Church Music'. The Joumal of the Sylvia Townsend Warner Society, 2011, pp. 69 - 88.

SPICER, P (1998) Herbert Howells. Bridgend, Seren Books.

TERRY, R. (1917) Letter dated 6 October, 1917. Royal College of Music, Howells Archive: $7832 / 358 \mathrm{~d}$. (1918) Damaged Letter, postmarked 16 January, 1918. Royal College of Music, Howells Archive reference $7832 / 358 \mathrm{e}$.

WARNER, S. T. (1967) T. H. White: A Biography. London, Jonathan Cape with Chatto \& Windus. (1994) ed. Claire Harman. The Diaries of Sy/via Townsend Warner. London:Chatto \& Windus.

Access to the Herbert Howells Archives at the Royal College of Music, London and permission to publish extracts from them was kindly given by Dr P Horton, Deputy Librarian. 